\title{
Weathering of Devonian monzogranites as recorded in the geochemistry of saprolites from the South Mountain Batholith, Nova Scotia, Canada
}

\author{
Anne Marie O’Beirne-Ryan* and Marcos Zentilli \\ Department of Earth Sciences, Dalhousie University, Halifax, Nova Scotia B3H 3J5 Canada \\ *Corresponding author<amryan@dal.ca>
}

Date received: 23 January 2006 Date accepted: 28 August 2006

\begin{abstract}
Parent mineralogy, paleoenvironment, and subsequent diagenetic and erosional history contribute to the nature of the paleoweathering profiles (saprolites) developed on the South Mountain Batholith. Saprolites of three different ages (pre-Carboniferous, pre-Triassic, and pre-Pleistocene) developed on Devonian monzogranite and exhibit increases in oxidation and hydration and decreases in rare earth elements with increasing weathering. In addition, changes in $\mathrm{Ca}, \mathrm{Ba}, \mathrm{Rb}, \mathrm{Zn}, \mathrm{Pb}, \mathrm{Co}$, and other elements in the oldest saprolite indicate element mobility during weathering. Reexposure of these partially weathered profiles at surface in today's acidic and oxygen-rich environment may result in further migration of elements from these saprolites.
\end{abstract}

\section{RÉSUMÉ}

La minéralogie originelle, le paléoenvironnement, et les antécédents diagénétiques et d'érosion subséquents sont autant de facteurs qui déterminent les profils de paléométéorisation (saprolithes) observés dans le batholithe de South Mountain. Des saprolithes de trois époques différentes (antérieures au Carbonifère, à l'ère triasique, et au Pléistocène) se sont formées sur du monzogranite. On observe une oxydation et une hydratation accrues, une diminution de la présence des éléments du groupe des terres rares, et une météorisation plus grande. De plus, des altérations de Ca, $\mathrm{Ba}, \mathrm{Rb}, \mathrm{Zn}, \mathrm{Pb}$, Co et d'autres éléments dans les saprolithes plus anciens indiquent le caractère meuble des éléments pendant la météorisation. Une nouvelle exposition de ces profils en partie météorisés dans le milieu acide et riche en oxygène d'aujourd'hui pourrait entraîner une autre migration des éléments contenus dans ces saprolithes.

[Traduit par la rédaction]

\section{INTRODUCTION}

Weathering profiles of three distinctly different ages have been identified on monzogranite of the South Mountain Batholith (O’Beirne-Ryan and Zentilli 2003) (Fig. 1): (I) a preCarboniferous weathering profile, $4-6 \mathrm{~m}$ thick, characterized by relithified clay-rich saprolite beneath a Carboniferous sedimentary sequence; (II) a pre-Triassic profile, approximately 30 $\mathrm{m}$ thick, characterized by unlithified saprolite beneath Triassic sandstone and shale; and (3) a pre-Pleistocene weathering profile with up to $3 \mathrm{~m}$ preserved, characterized by an arenaceous saprolite beneath Pleistocene till. The first two paleo-profiles are observed in drill core whereas the youngest profile is observed in outcrops of monzogranite and other felsic units of the South Mountain Batholith.

The preserved portions of the weathering profiles developed on the South Mountain Batholith and in particular, the sections of pre-Pleistocene age, represent either (I) the lowest, least weathered part of a thicker, more complete weathering profile, the bulk of which has now been removed by erosion, or (II) an arrested stage in the development of a weathering profile, representing an early, incipient weathering event (O'Beirne-Ryan and Zentilli 2003). As a result of this incomplete weathering, a considerable amount of readily available soluble material remains in the younger saprolites, and they are "primed" for further chemical alteration. In combination with the intensity of microfractures developed within the saprolites with a resulting increase in surface area for reaction, and the acidic precipitation currently prevailing throughout Nova Scotia, these saprolites are potential elemental sieves if disturbed or exposed at surface. The purpose of this study was to establish the nature of the chemical changes which occurred in chemi- 
cally similar rocks at different times in the geologic past, in order to access the potential for further changes when these partially eroded and incompletely weathered saprolites are reexposed at surface today. In recent years, a number of these saprolite locations have been subjected to quarrying for use as road bed material, and their friable and permeable nature means that water and air flow-through is high. In re-exposing these profiles, it is possible that loosely bound elements may be mobilised under conditions of increased Eh and decreased $\mathrm{pH}$, as might be expected at surface today. Consequently the term "elemental sieve" is used to denote the possibility of further leaching of elements from these saprolites under present-day changing conditions.

This paper summarises the geochemical changes that occurred in saprolites developed on monzogranite of the South Mountain Batholith, and discusses the implications of these
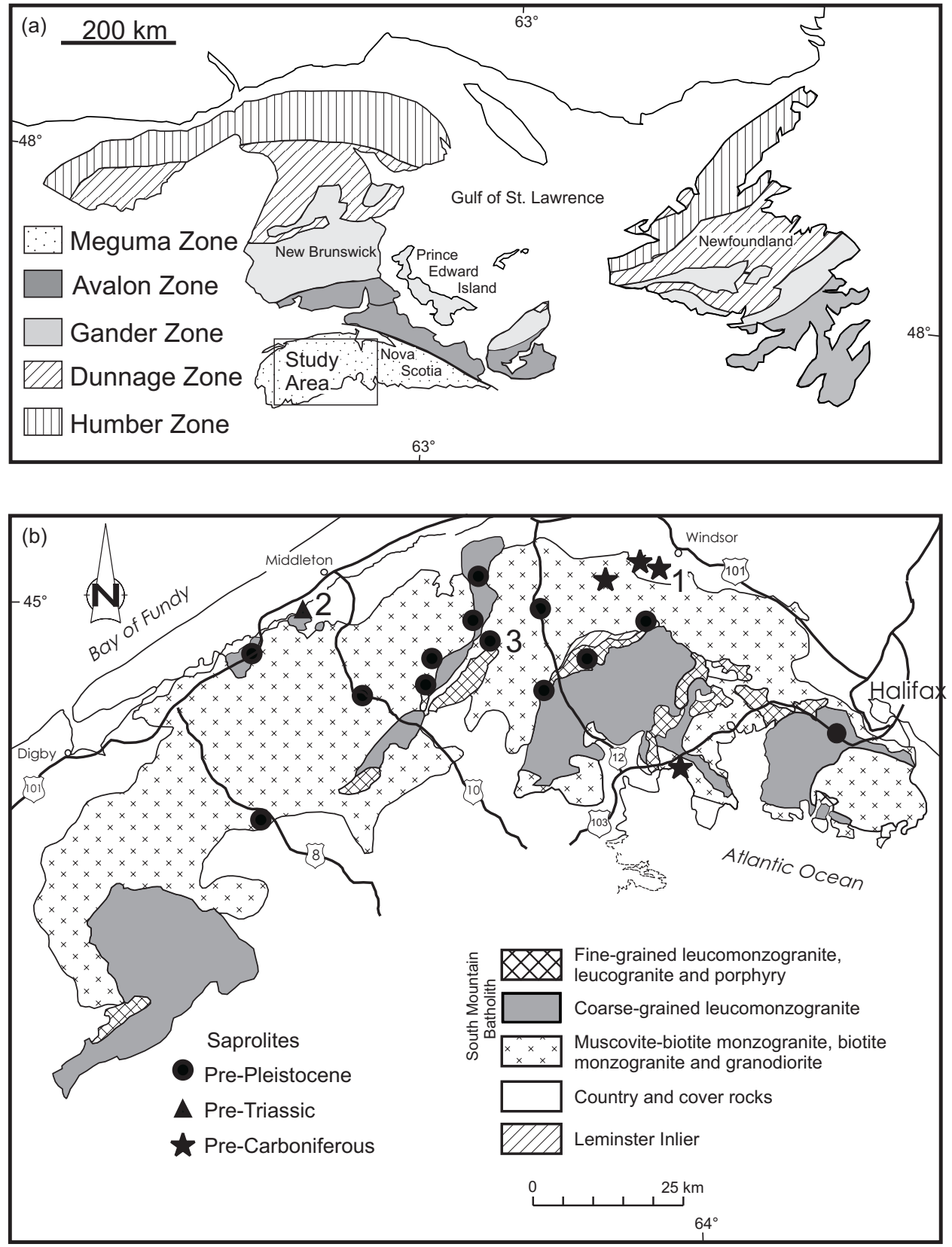

Fig. 1 A. Location of the study area and general geological setting of the northern Appalachians, after Williams (1995). B. Generalized map of South Mountain Batholith, Nova Scotia, showing localities and ages of saprolites suites analysed in this study: 1, Castlefrederick, pre-Carboniferous; 2, pre-Triassic; and 3, Hardwood Lake, pre-Pleistocene. 
changes in relation to mobilization or retention of elements when these profiles are re-exposed at surface today.

\section{SAMPLING PROCEDURES AND ANALYTICAL METHODS}

Monzogranite of the South Mountain Batholith (SMB), Nova Scotia, Canada, consists of subequal quartz, plagioclase, and alkali feldspar, and $8-15 \%$ biotite. Dominant accessory minerals include apatite, zircon, and titanite. Sample suites from the pre-Pleistocene, the pre-Triassic, and the pre-
Carboniferous saprolite profiles developed on the monzogranite were analyzed for major and trace elements, rare earth elements (REEs), and loss on ignition (LOI) (Table 1, Fig. 2). The pre-Pleistocene suite includes three samples of increasing weathering intensity based on field evidence (O’Beirne-Ryan and Zentilli 2003). The pre-Triassic monzogranite saprolite with whole-rock composition similar to the monzogranite of the pre-Pleistocene profile, provides the most complete, undisturbed record of weathering. Five samples of increasing weathering intensity were analysed from this profile. The parent monzogranite of the pre-Carboniferous saprolite is chemically similar to parent monzogranites of younger saprolites.

\section{Pre-Pleistocene Horizon}

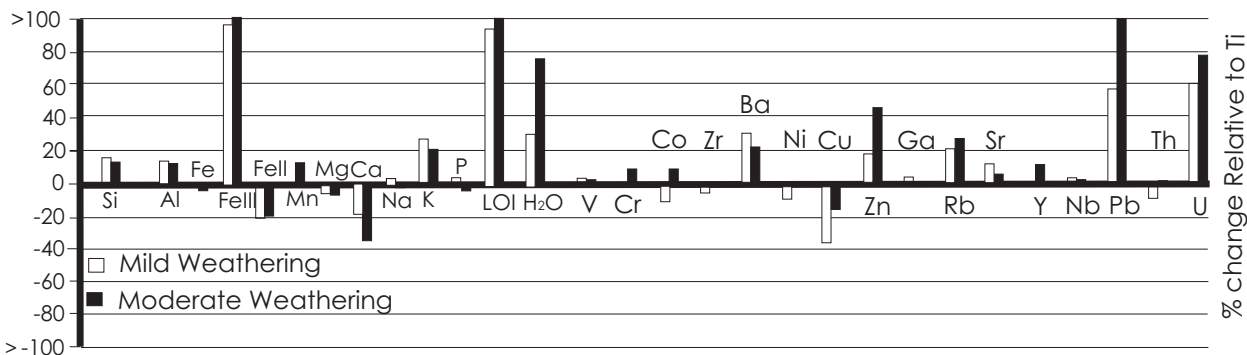

\section{Pre-Triassic Horizon}

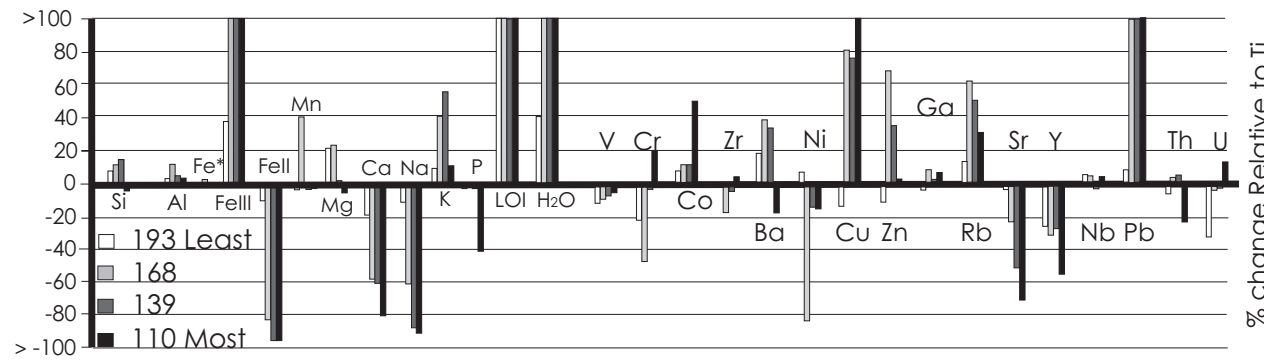

Pre-Carboniferous

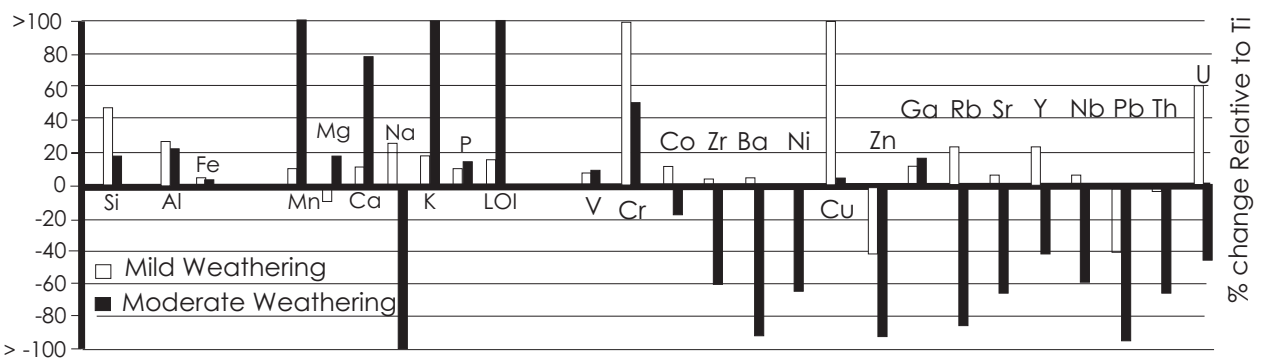

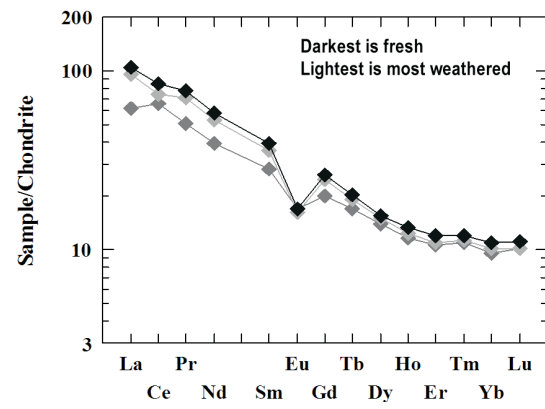
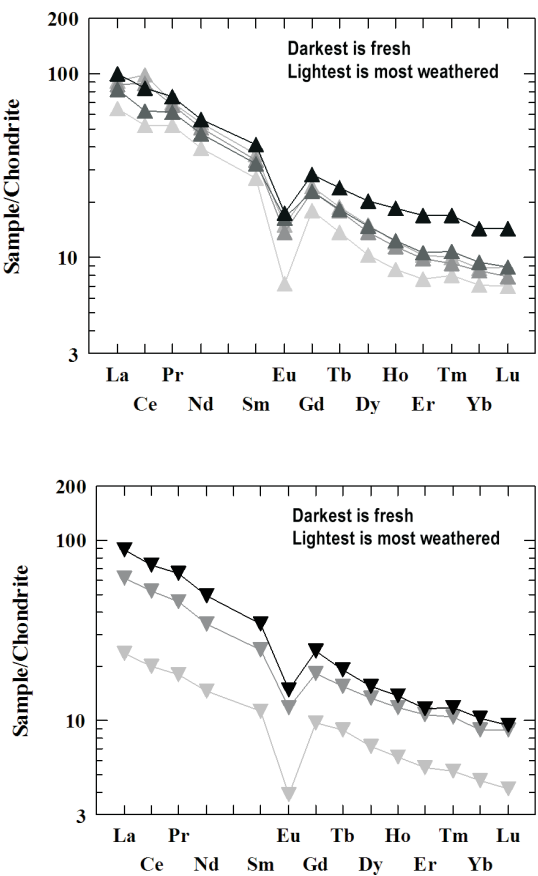

Fig. 2 Geochemical data normalized to fresh parent monzogranite; parent analyses are represented by the x-axis. Data have been normalized to Ti for major and trace elements, and to chondrite for REEs for pre-Pleistocene (Hardwood Lake), pre-Triassic, and pre-Carboniferous (Castlefrederick) saprolites. Mild weathering refers to solid rock which is easily broken with a hammer, and moderate weathering refers to crumbly, in situ material. $\mathrm{Fe}^{2+}, \mathrm{Fe}^{3+}$, and $\mathrm{H}_{2} \mathrm{O}^{+}$were not measured for the pre-Carboniferous saprolite. 
Table 1. Major, trace, and rare earth element geochemical data for the pre-Pleistocene (Hardwood Lake), pre-Triassic, and preCarboniferous (Castlefrederick 1) saprolites.

\begin{tabular}{|c|c|c|c|c|c|c|c|c|c|c|c|}
\hline & \multicolumn{3}{|c|}{$\begin{array}{l}\text { Pre-Pleistocene } \\
\text { Hardwood Lake }\end{array}$} & \multicolumn{5}{|c|}{ Pre-Triassic } & \multicolumn{3}{|c|}{$\begin{array}{c}\text { Pre-Carboniferous } \\
\text { Castlefrederick } 1\end{array}$} \\
\hline & $112 \mathrm{f}$ & $113 \mathrm{Aw}$ & $144 w w$ & $2-201$ & $2-193$ & $2-168$ & $2-139$ & $2-110$ & $1134 f$ & $1126 \mathrm{w}$ & $1119 w w$ \\
\hline \multicolumn{12}{|c|}{ Major elements $(\%)^{1}$} \\
\hline $\mathrm{SiO}_{2}$ & 67.04 & 67.83 & 67.48 & 68.03 & 67.88 & 67.73 & 69.46 & 66.87 & 67.45 & 70.95 & 65.15 \\
\hline $\mathrm{TiO}_{2}$ & 0.76 & 0.66 & 0.68 & 0.65 & 0.61 & 0.59 & 0.59 & 0.68 & 0.55 & 0.40 & 0.45 \\
\hline $\mathrm{Al}_{2} \mathrm{O}_{3}$ & 15.26 & 15.23 & 15.06 & 15.10 & 14.41 & 14.99 & 14.41 & 16.44 & 15.35 & 14.09 & 15.31 \\
\hline $\mathrm{Fe}_{2} \mathrm{O}_{3}{ }^{\mathrm{t}}$ & 5.38 & 4.65 & 4.86 & 4.58 & 4.27 & 4.15 & 4.10 & 4.77 & 4.38 & 3.37 & 3.82 \\
\hline $\mathrm{Fe}_{2} \mathrm{O}_{3}{ }^{2}$ & 1.03 & 1.77 & 1.83 & 1.00 & 1.28 & 3.85 & 3.92 & 4.55 & n.m. & n.m. & n.m. \\
\hline $\mathrm{FeO}^{2}$ & 3.91 & 2.59 & 2.72 & 3.22 & 2.69 & 0.27 & 0.16 & 0.20 & n.m. & n.m. & n.m. \\
\hline $\mathrm{MnO}$ & 0.09 & 0.08 & 0.09 & 0.07 & 0.07 & 0.09 & 0.06 & 0.07 & 0.10 & 0.08 & 0.66 \\
\hline $\mathrm{MgO}$ & 1.30 & 1.09 & 1.11 & 1.13 & 1.28 & 1.25 & 1.02 & 1.11 & 1.10 & 0.72 & 1.06 \\
\hline $\mathrm{CaO}$ & 1.96 & 1.37 & 1.13 & 2.09 & 1.60 & 0.80 & 0.71 & 0.32 & 2.13 & 1.69 & 3.07 \\
\hline $\mathrm{Na}_{2} \mathrm{O}$ & 3.11 & 2.81 & 2.76 & 3.06 & 2.52 & 1.07 & 0.25 & 0.20 & 2.99 & 2.72 & 0.01 \\
\hline $\mathrm{K}_{2} \mathrm{O}$ & 4.01 & 4.47 & 4.33 & 4.19 & 4.25 & 5.25 & 5.78 & 4.82 & 4.36 & 4.47 & 0.20 \\
\hline $\mathrm{P}_{2} \mathrm{O}_{5}$ & 0.30 & 0.27 & 0.26 & 0.22 & 0.21 & 0.20 & 0.20 & 0.13 & 0.23 & 0.18 & 0.21 \\
\hline $\mathrm{LOI}^{3}$ & 0.80 & 1.38 & 1.88 & 0.98 & 2.06 & 4.94 & 4.29 & 5.13 & 1.05 & 0.85 & 10.22 \\
\hline $\mathrm{H}_{2} \mathrm{O}^{+4}$ & 0.89 & 1.00 & 1.42 & 0.83 & 1.08 & 2.17 & 2.51 & 3.80 & n.m. & n.m. & n.m. \\
\hline \multicolumn{12}{|c|}{ Trace elements (ppm, except $\mathrm{Hg}$ and $\mathrm{Au}$ in $\mathrm{ppb}$ ) } \\
\hline $\mathrm{V}$ & 94 & 85 & 86 & 83 & 78 & 68 & 70 & 83 & 76 & 59 & 68 \\
\hline $\mathrm{Cr}$ & 26 & 23 & 26 & 25 & 18 & 12 & 22 & 31 & 22 & 34 & 27 \\
\hline Co & 13 & 10 & 13 & 11 & 11 & 11 & 11 & 17 & 10 & 8 & 7 \\
\hline $\mathrm{Zr}^{5}$ & 225 & 186.6 & 201 & 230.4 & 206.4 & 174 & 200.6 & 247.6 & 201.7 & 151 & 65 \\
\hline $\mathrm{Ba}$ & 704 & 806 & 785 & 773 & 847 & 956 & 921 & 664 & 643 & 489 & 37 \\
\hline $\mathrm{Ni}$ & 10 & 8 & 9 & 9 & 9 & 1 & 7 & 8 & 11 & 4 & 3 \\
\hline $\mathrm{Cu}$ & 14 & 8 & 11 & 7 & 7 & 14 & 11 & 19 & $<4$ & 5 & $<4$ \\
\hline $\mathrm{Zn}$ & 84 & 86 & 111 & 71 & 70 & 107 & 85 & 75 & 121 & 51 & 6 \\
\hline $\mathrm{Ga}$ & 23 & 21 & 22 & 21 & 19 & 20 & 19 & 23 & 22 & 18 & 21 \\
\hline $\mathrm{Rb}$ & 192 & 206 & 220 & 149 & 157 & 218 & 200 & 202 & 173 & 156 & 15 \\
\hline $\mathrm{Sr}$ & 149 & 143 & 139 & 141 & 130 & 99 & 64 & 43 & 129 & 97 & 34 \\
\hline $\mathrm{Y}^{5}$ & 28.87 & 25.28 & 28.16 & 41.59 & 28.44 & 25.36 & 27.15 & 19.84 & 31.5 & 27.92 & 14.62 \\
\hline $\mathrm{Nb}^{5}$ & 14.3 & 12.8 & 13.1 & 13.9 & 13.5 & 12.8 & 12.2 & 14.7 & 13.2 & 10 & 4.6 \\
\hline $\mathrm{Pb}$ & 17 & 23 & 36 & 20 & 20 & 38 & 46 & 98 & 53 & 23 & $<3$ \\
\hline $\mathrm{Th}^{5}$ & 12.41 & 9.99 & 11.3 & 13.23 & 11.34 & 12.3 & 12.5 & 10.38 & 11.62 & 8.22 & 3.1 \\
\hline $\mathrm{U}^{5}$ & 3.465 & 4.872 & 5.554 & 4.304 & 2.642 & 3.581 & 3.797 & 5.017 & 3.165 & 3.637 & 1.382 \\
\hline $\mathrm{Hg}^{7}$ & 1.9 & 1.2 & 1.6 & 1.2 & 3.1 & 2.2 & b.d. & 4.7 & n.m. & n.m. & n.m. \\
\hline $\mathrm{Cd}^{6}$ & b.d. & b.d. & 7 & 0.2 & 0.2 & 0.2 & b.d. & 0.3 & n.m. & n.m. & n.m. \\
\hline $\mathrm{As}^{6}$ & 6 & 6 & 14 & 8 & 9 & 12 & 14 & 35 & n.m. & n.m. & n.m. \\
\hline $\mathrm{Li}^{6}$ & 125 & 109 & 115 & 65 & 61 & 48 & 39 & 36 & n.m. & n.m. & n.m. \\
\hline $\mathrm{Sc}^{6}$ & 10 & 9 & 8 & 9 & 8 & 8 & 7 & 9 & n.m. & n.m. & n.m. \\
\hline $\mathrm{Au}^{6}$ & b.d. & 1 & 2 & 1 & 1 & b.d. & b.d. & b.d. & n.m. & n.m. & n.m. \\
\hline $\mathrm{Mo}^{6}$ & b.d. & b.d. & 8 & b.d. & 1 & b.d. & b.d. & 1 & n.m. & n.m. & n.m. \\
\hline \multicolumn{12}{|c|}{ Rare earth elements (ppm) ${ }^{5}$} \\
\hline Cs & 11.931 & 12.071 & 15.359 & 8.882 & 13.992 & 28.577 & 23.694 & 22.28 & 9.94 & 7.131 & 0.286 \\
\hline $\mathrm{Hf}$ & 6.2 & 5.1 & 5.5 & 6.3 & 5.6 & 4.8 & 5.4 & 6.6 & 5.6 & 4.2 & 1.9 \\
\hline $\mathrm{Ta}$ & 1.64 & 1.40 & 1.46 & 1.06 & 1.03 & 1.04 & 0.97 & 1.16 & 1.14 & 0.91 & 0.40 \\
\hline $\mathrm{La}$ & 38.35 & 22.79 & 34.97 & 36.74 & 30.33 & 32.27 & 33.46 & 23.79 & 32.57 & 22.76 & 8.6 \\
\hline $\mathrm{Ce}$ & 80.85 & 62.9 & 70.77 & 79.7 & 60.05 & 84.4 & 94.3 & 50.18 & 69.38 & 49.82 & 19.12 \\
\hline $\operatorname{Pr}$ & 10.636 & 6.956 & 9.694 & 10.305 & 8.529 & 9.331 & 9.554 & 7.185 & 8.943 & 6.271 & 2.478 \\
\hline $\mathrm{Nd}$ & 41.52 & 27.92 & 37.71 & 40.02 & 33.77 & 35.94 & 38.16 & 28.09 & 34.86 & 24.46 & 10.34 \\
\hline $\mathrm{Sm}$ & 9.11 & 6.52 & 8.35 & 9.45 & 7.49 & 7.83 & 8.43 & 6.28 & 8.00 & 5.74 & 2.62 \\
\hline $\mathrm{Eu}$ & 1.486 & 1.473 & 1.407 & 1.511 & 1.425 & 1.203 & 1.3 & 0.626 & 1.282 & 1.032 & 0.337 \\
\hline $\mathrm{Gd}$ & 8.065 & 6.079 & 7.579 & 8.611 & 6.975 & 7.039 & 7.423 & 5.52 & 7.423 & 5.587 & 2.973 \\
\hline $\mathrm{Tb}$ & 1.173 & 0.977 & 1.109 & 1.394 & 1.068 & 1.038 & 1.094 & 0.794 & 1.111 & 0.899 & 0.518 \\
\hline Dy & 5.883 & 5.288 & 5.737 & 7.695 & 5.684 & 5.243 & 5.753 & 3.947 & 5.931 & 5.075 & 2.729 \\
\hline Ho & 1.143 & 0.99 & 1.054 & 1.591 & 1.058 & 0.969 & 1.032 & 0.738 & 1.162 & 1.007 & 0.533 \\
\hline Er & 2.992 & 2.63 & 2.749 & 4.198 & 2.643 & 2.457 & 2.584 & 1.913 & 2.916 & 2.684 & 1.368 \\
\hline $\mathrm{Tm}$ & 0.426 & 0.392 & 0.403 & 0.604 & 0.384 & 0.333 & 0.355 & 0.284 & 0.419 & 0.374 & 0.188 \\
\hline $\mathrm{Yb}$ & 2.72 & 2.38 & 2.53 & 3.58 & 2.33 & 2.11 & 2.17 & 1.75 & 2.55 & 2.21 & 1.16 \\
\hline $\mathrm{Lu}$ & 0.427 & 0.383 & 0.39 & 0.549 & 0.336 & 0.302 & 0.341 & 0.265 & 0.362 & 0.337 & 0.159 \\
\hline
\end{tabular}

Abbreviations: After sample numbers: $\mathrm{f}=$ fresh, $\mathrm{w}=$ moderatly weathered, $\mathrm{ww}=$ most weathered. In analyses: $\mathrm{n} . \mathrm{m} .=$ not measured, b.d. = below detection limit.

Notes: 1. All samples analysed using XRF except as follows. 2. $\mathrm{Fe}^{3+}$ and $\mathrm{Fe}^{2+}$ analysed by titration at Daltech, Halifax. 3. LOI = determined by weight difference after heating to $250^{\circ} \mathrm{C}$ for $1.5 \mathrm{~h}$ followed by heating to $1050^{\circ} \mathrm{C}$ for $2.5 \mathrm{~h} .4 . \mathrm{H}_{2} \mathrm{O}^{+}$analysed at Daltech, Halifax. 5 Analysis using ICP-MS at Geo Labs, Ontario. 6. Analysis using aqua regia dissolution at Bondar Clegg Laboratories, Vancouver. 7. Hg analysed using Cetac Cold Vapour Atomic Absorption unit at Bondar Clegg Laboratories, Vancouver. 8. Ag, Bi, Sb, Sn, W, and S were analysed but below detection limit in all samples. 
Three samples of increasing weathering intensity from one of the pre-Carboniferous profiles are also included in this study (Fig. 1). Major and trace elements, with the exception of $\mathrm{Zr}$, $\mathrm{Y}, \mathrm{Nb}$, Th, and $\mathrm{U}$, were analysed by XRF; $\mathrm{Zr}, \mathrm{Y}, \mathrm{Nb}, \mathrm{Th}, \mathrm{U}$, and REEs, were analysed using ICP-MS; $\mathrm{Fe}^{3+}$ was analysed by titration; and LOI was determined by heating to $250^{\circ} \mathrm{C}$ for 1.5 hours, then at $1050^{\circ} \mathrm{C}$ for 2.5 hours (David Slaunwhite, Regional Geochemical Centre, Nova Scotia, Saint Mary's University, personal communication 2005). Details of sample preparation, analysis, and precision are given in O'Beirne-Ryan (2006). Because chemical weathering is not necessarily an isovolumetric process (Nesbitt 1979; Cramer and Nesbitt 1983), the geochemical data were normalized against Ti (Fig. 2) using the formula of Nesbitt (1979):

$$
\% \text { change of element } \mathrm{X}=\left[(\mathrm{X} / \mathrm{Ti})_{\text {sample }} /(\mathrm{X} / \mathrm{Ti})_{\text {parent }}-1\right] .100
$$

\section{RESULTS}

\section{Major element changes during weathering}

Relative to the least altered parent rock, the pre-Triassic and pre-Pleistocene saprolite sample suites show notable increases of $20 \%$ or more in $\mathrm{Fe}^{3+}, \mathrm{LOI}$, and $\mathrm{K}$. The pre-Triassic suite shows decreases of more than $20 \%$ in $\mathrm{Fe}^{2+}$, Ca, and $\mathrm{Na}$. In the older pre-Carboniferous suite, LOI, Ca, and Mn content increases, whereas $\mathrm{Na}$ and $\mathrm{K}$ decrease with increased degree of weathering. Among the three saprolite suites the total iron content does not change significantly throughout the weathering process. Other major element changes are inconsistent between samples, although in the pre-Triassic suite $\mathrm{P}$ tends to decrease with increasing degree of weathering.

\section{Trace element changes during weathering}

Pre-Triassic and the pre-Pleistocene saprolite samples (Fig.2) show some broadly similar trends: $\mathrm{Rb}, \mathrm{Ba}, \mathrm{Pb}, \mathrm{Zn}$, and $\mathrm{Co}$ tend to increase during weathering relative to Ti in both suites. $\mathrm{Cu}$ increases dramatically in the pre-Triassic suite. No trace element is notably depleted in the pre-Pleistocene suite; however, in the pre-Triassic suite $\mathrm{Sr}$ and $\mathrm{Y}$ exhibit notable decreases. The pre-Carboniferous suite is significantly depleted in most trace elements as weathering intensity increases.

\section{Rare earth element changes during weathering}

Rare earth element data are presented normalized to chondrite (Fig. 2). In all three sample suites, there is a general tendency for decrease, or little change, in rare earth elements (REEs) with increasing degree of weathering. In the pre-Triassic suite there is a tendency towards fractionation of the REEs, with greater decreases recorded in the heavy REEs than in the light REEs; the opposite trend is observed in the younger prePleistocene suite. However, sub-parallel trend lines exist for the pre-Carboniferous suite, suggesting minimal fractionation during this weathering event.

\section{DISCUSSION}

The dominant and most pervasive features of weathering in the various profiles from the South Mountain Batholith are the processes of $(\mathrm{i})$ oxidation as recorded in the changing ratio of $\mathrm{Fe}^{3+}: \mathrm{Fe}^{2+}$, and (ii) hydration, as recorded in the increased water content of the more weathered samples, a reflection of the development of clay mineralogy at the expense of the feldspars and biotite. Calcium also shows significant depletion in the younger suites, consistent with observations elsewhere (Islam et al. 2002; Nesbitt et al.1980). The retention of alkali elements throughout the sequence in the younger suites confirms either arrested or less intense weathering events or erosion of the more weathered upper profiles, leaving the profiles incompletely preserved. Although Nova Scotia's cool temperate climate is not likely to induce intense weathering of the exposed pre-Pleistocene profiles today, the impact of acid rain on changing the chemistry of these profiles is possible. For example, $U$ that was mobilized from weathering of biotite during the initial stage of weathering was adsorbed or relocated on iron and titanium oxides. Under conditions of reduced $\mathrm{pH}$ such as is typical of acid rain, particularly where Eh is high, this adsorbed uranium can be mobilized and migrate into ground or surface waters.

The weathering geochemistry of the pre-Carboniferous suite is different than the younger two suites although the behaviour in terms of LOI is very similar $\left(\mathrm{Fe}^{2+}\right.$ was not measured for this suite). The less systematic behaviour of most other elements in this suite suggests a more complex origin of the geochemical signature. The magnitude of the geochemical changes from the lower to upper portion of the saprolite suggests that the initial weathering process was more intense than in the younger pre-Triassic and pre-Pleistocene suites. The geochemical signature of this weathering event is more typical of a tropical weathering environment, and is consistent with the sub-equatorial location of Nova Scotia during the Devonian-Carboniferous (e.g., Calder 1998). The increased complexity of the elemental behaviour compared to that of the 2 younger suites also reflects the superimposed relithification process on this saprolite. Ryan and Zentilli (1993) established burial temperatures of upwards of $150^{\circ} \mathrm{C}$ during the Permian for strata overlying the pre-Carboniferous paleosaprolite. The increase in $\mathrm{Ca}$ and $\mathrm{Mn}$ in the weathered samples is not typical of the behaviour of these elements in the younger suites, or in weathering profiles elsewhere (Middleburg et al. 1988; van der Weijden and van der Weijden 1995). The increase in Ca and $\mathrm{Mn}$ in this pre-Carboniferous saprolite can be attributed to the addition, post-weathering, of $\mathrm{Ca}$ and $\mathrm{Mn}$; thin section textural and mineralogical evidence further supports the later addition of $\mathrm{Ca}, \mathrm{Mn}$, and other elements to the system (O'Beirne-Ryan and Zentilli 2006). The increase in Mn levels is consistent with 
Mn mineralization found in granitoids in the surrounding area (Chatterjee 1983).

In the younger saprolites (pre-Triassic and pre-Pleistocene) the chemical changes reflect the mineralogy of the monzogranite and its response to weathering conditions. Even in the preTriassic profile, where over $30 \mathrm{~m}$ of saprolite is preserved, it is only in the uppermost levels that the alkali elements show relative depletion, suggesting that more temperate conditions prevailed during the development of both the pre-Triassic and pre-Pleistocene profiles, rather than the more intense conditions prevailing during the pre-Carboniferous event. Middleburg et al. (1988) discussed the behaviour of the redox elements during weathering. In the younger saprolites of the South Mountain Batholith, $\mathrm{Fe}^{3+}$ increases of $>100 \%$ confirm the significance of oxygen, even in the lowermost levels of the weathering profile. The variable behaviour of $\mathrm{U}, \mathrm{V}, \mathrm{Th}$, and other redox-sensitive elements may be explained by retention of these elements in insoluble or weakly soluble phases (zircon, for example) or by partial adsorption of these elements on the newly formed Fe-Ti oxide and oxyhydroxide on clay minerals. Further studies on the actual distribution of uranium in these weathered profiles is ongoing, as unlike uranium in resistate minerals such as zircon, uranium adsorbed onto secondary minerals or concentrated in apatite may be liberated and mobilized under changing Eh-pH conditions. U-mineralization in Lower Carboniferous arkose formed from granitic rocks of the South Mountain Batholith (O'Reilly et al. 1982) confirms that U may be mobilized from these granitic rocks under favourable conditions; it is possible that the impact of acid precipitation on recently exposed saprolites may provide the impetus for mobilization of U, or other redox-sensitive elements. Furthermore, Kronfeld et al. (2004) concluded that present-day locally elevated levels of uranium in groundwaters are attributable to weathering of zones of uranium mineralization.

The REEs in all suites are increasingly depleted on weathering. This depletion is counter to the trends observed by Nesbitt (1979) and Middleburg et al. (1988), but similar to that documented by Koons (1978). However, Nesbitt (1979) indicated that the behaviour of the REEs is dependant on $\mathrm{pH}$ conditions, and on which minerals host the REEs. If the REEs of the South Mountain Batholith are concentrated in apatite or some other mineral which weathers more readily than zircon, then the REEs may be mobilized more readily (Nesbitt, 1979). Aqua regia dissolution of saprolite samples causes the release of $\mathrm{La}$ and $\mathrm{Y}$ but not of $\mathrm{Zr}$, suggesting that at least some of the REEs are located in phases more soluble than zircon. Nesbitt (1979) concluded that increasing pH may result in the mobilized REEs becoming concentrated in the secondary minerals. The consistent depletion of REEs in all of the monzogranite saprolites on the South Mountain Batholith included in this study suggests that the behaviour of the REES is related to weathering of their host minerals, rather than changing conditions during weathering.

\section{CONCLUSIONS}

1. Weathering profiles developed on monzogranite of the Devonian South Mountain Batholith at three different times in the geologic past.

2. The profiles show different chemical patterns according to the prevailing weathering conditions during their formation.

3. Although overall dramatic depletion of trace elements occurred only in the pre-Carboniferous saprolite, a redistribution of elements has occurred in all profiles, and it is possible that these elements could be more readily mobilized under changing conditions at the Earth's surface today.

4. Whereas similar parent mineralogy and chemistry occur at the sampled profiles regardless of age of weathering, and chemical analyses of the weathered products of these saprolites indicates different weathering conditions occurred at different times in the past, the shared distribution characteristics of the REEs for all ages of weathering suggests that mineralogy rather than weathering conditions controls the REE patterns in each of the three saprolite suites studied.

\section{ACKNOWLEDGEMENTS}

The authors thank John Wightman and Larry Riteman for providing samples from drill core. Thanks are also extended to Jarda Dostal for helpful comments on early drafts of this paper, and to Steve McCutcheon and Allen Seaman, for review and suggestions on the final manuscript.

\section{REFERENCES}

Calder, J.H. 1998. The Carboniferous evolution of Nova Scotia. In Lyell: the past is the key to the present. Edited by D. Blundell and A.C. Scott. Geological Society of London Special Publication, pp. 296-331.

Chatterjee, A.K. 1983. Metallogenic map of Nova Scotia. Map ME-1983-5, Nova Scotia Department of Natural Resources.

Cramer, J.J. \& Nesbitt, H.W. 1983. Mass-balance relations and trace-element mobility during continental weathering of various igneous rocks. Sciences Geologiques. Memoire, 73, pp. 63-73.

Islam, M.R., Peuraniemi, V., Aario, R. \& Rojstaczer, S. 2002. Geochemistry and mineralogy of saprolite in Finnish Lapland. Applied Geochemistry 17, pp. 885-902.

Koons, R.D. 1978. Behavior of trace and major elements and minerals during early stages of weathering of diabase and granite in Central Wisconsin. Ph.D. Thesis, University of Wisconsin-Madison. 243 p.

Kronfeld, J., Godfrey-Smith, D.I., Johannessen, D. AND Zentilli, M. 2004. Uranium series isotopes in the Avon 
Valley, Nova Scotia. Journal of Environmental Radioactivity, 73, pp. 335-352.

Middelburg, J.J., van der Weijden, C.H., \& Woittiez, J.R.W. 1988. Chemical processes affecting the mobility of major, minor and trace elements during weathering of granitic rocks. Chemical Geology, 68, pp. 253-273.

Nesbitt, H.W. 1979. Mobility and fractionation of rare earth elements during weathering of a granodiorite. Nature, 279, pp. 206-210.

Nesbitt, H.W., Markovics, G., \& Price, R.C. 1980. Chemical processes affecting alkalis and alkaline earths during continental weathering. Geochimica et Cosmochimica Acta, 44, pp. 1659-1666.

O'BEIRNE-Ryan, A.M. 2006. Weathering history of granitoids of the South Mountain Batholith, N.S., Canada: Mineralogy, geochemistry, and environmental implications of saprolite. Unpublished $\mathrm{PhD}$ thesis, Dalhousie University. 239 p.

O’Beirne-Ryan, A.M., \& Zentilli, M. 2006. Weathered granites as potential chemical sieves: impacts of ancient pre-glaciation weathering on the granitoids of south-western Nova Scotia and the environment. $32^{\text {nd }}$ Colloquium and Annual Meeting, Atlantic Geoscience Society, Abstract with programs, pp. 54-55.
O’Beirne-Ryan, A.M. \& Zentilli, M. 2003. Paleoweathered surfaces on granitoids of Southern Nova Scotia: Paleoenvironmental implications of saprolites. Canadian Journal of Earth Sciences, 40, pp. 805-817.

O’Reilly, G.A., Farley, E.J., \& Charest, M.H. 1982. Metasomatic and hydrothermal deposits of the New Ross - Mahone Bay area, Nova Scotia. Paper ME 1982-2, Nova Scotia Department of Natural Resources. 96 p.

Ryan, R. J. \& Zentilli, M. 1993. Allocyclic and thermochronological constraints on the evolution of the Maritimes Basin, Atlantic Geology, 29, pp. 187-197.

VAN DER Weijden, C.H. AND VAN DER WeIJden, R.D. 1995. Mobility of major, minor, and some redox-sensitive trace elements and rare-earth elements during weathering of four granitoids in central Portugal. Chemical Geology 125, pp. 149-167.

Williams, H. 1995. Introduction, Chapter 1. In Geology of the Appalachian-Caledonian Orogen in Canada and Greenland. Edited by H. Williams; Geological Survey of Canada, Geology of Canada, 6, pp. 1-9.

Editorial responsibility: Donald L. Fox 
